\title{
Analysis of the Impact of Globalization on the Palestinian Economy
}

\author{
Huiping Liu \\ School of Marxism, Qufu Normal University \\ Rizhao 276826, China \\ E-mail: zhang2002m@126.com
}

\begin{abstract}
The Palestinian economy is highly dependent on the Israeli economy. With the impact of economic globalization, the Palestinian economy can not develop independently. Palestinian blindly followed free-market economic policies resulting in many problems, such as the serious reflux of the Palestinian social funds, the improper investment direction, abnormal structure, subject to the Israeli economy and increasingly sharp polarization and corruption.
\end{abstract}

\section{Keywords: Globalization, Palestine, Economy, Israel}

Developing countries were under the control of or dependent on developed countries to different extent in many ways during the globalization process in current world, so the current globalization showed a strong trend of Westernization or Americanization. Globalization is a "double-edged sword" for the almost developing countries that accepted globalization; for it not only brought some development opportunities, but also posed serious challenges. This made some developing countries' leaders attribute the domestic economic difficulties to economic globalization at the Ninth United Nations Conference. Tanzanian President Benjamin William Mkapa said: "The countries had paid a huge social cost, including unemployment, health, health care, the reduce costs in education, and Unlimited instability because they had been liberalized and privatized by the control of the World Bank and IMF. Opening our national economy was always a question of our national economy. Our country's future was extremely bleak in global economic integration."(Liu, 1997, p.142) But no one could escape the reality of globalization. This paper attempts to analyze the influence of globalization on the West Bank and Gaza Strip. This regional economy started to attach to the Israeli economy after the "Six Day War". The Israeli economy was highly dependent on global economic organizations: the World Bank and International Monetary Fund. Although the two parts of the land was taken over by the Palestinian Authority, its economy was still dominated by Israel's economic policy, the World Bank, International Monetary Fund and the U.S., which was necessary and the choice of last resort for the Palestinians.

\section{Palestinian economic condition}

Israel occupied the West Bank and Gaza Strip in "Six Day War", and the Israeli military government signed a series of military orders to confine the residents of the occupied territories in production and living, more than half of which was related to economic issues. These military orders cut off the relation between the occupied territories and the outside world, which changed Israel into its supplier in production and daily necessities. More than $90 \%$ of all goods imported from Israel or through Israel in the occupied territories. And Israeli collected heavy taxes on commodities that were produced by non-Israeli but delivered to the West Bank and Gaza Strip by Israel, which made Palestine greatly reduce the trade with the surrounding countries, thus Israel became Palestinian One-way trading partners in fact. Namely only permitted the Israeli Goods free dump to the West Bank and Gaza Strip, and Palestinian commodities that exported to Israel were variously restricted. Meanwhile, Israel prohibited the Palestinians carrying out their business license for production and business activities in the cities; the Israel expropriated peasant land, built settlements, and controls the water in rural areas. In this case, many Palestinians entered Israel for work in order to make a living and provided the cheap labor for Israel. Palestinian economy emerged a serious setback from 1978 to 1988. The Israel adjusted the economic infrastructure in the occupied territories, leading to the Palestinian economy's dependence on the Israeli economy.

The "Oslo agreement" provided a framework about economic activity for the West Bank and Gaza Strip in September 1993. However, this framework gave Israel right to control land, labor and capital and other production factors, and control the external borders and the surrounding areas of Palestine. In fact, Israel still maintained complete control of the Palestinian economic by controlling the main factors of production (land, water, labor and capital) as well as border crossings, and its control almost had no any challenge. Israel 
continued to plunder the Palestinian land, driving them to leave their homes. It was only seven years from the "Oslo Agreement" to the September 2000. Israel annexed thousands of acres land (mostly agricultural land) in the West Bank and Gaza Strip, using it to expand settlements and build roads, so the population in Israeli settlements also doubled. "The Paris Economic Memorandum" Signed in 1994 was even worse than the "Oslo agreement" because it ignored the Palestinians' sovereignty over the occupied territories and thought that Palestinians could not formulate true economic development strategy so it need to continue to rely on Israel. Israel supervised the freedom of import and export in occupied territories and explicitly restricted the import and export of goods in the types and quantities in the occupied territories, and repeatedly blocked the West Bank and Gaza Strip by the pretext of security, cut off the West Bank and Gaza seaport linking with external markets, brought great disasters to the Palestinian economy, labor, and trade causing serious economic recession, so the national income appeared sharp drop. Blockade made Gaza's GDP decrease by $39.6 \%$ only in 1996, a decrease of $18.2 \%$ in West Bank. The unemployment rate was up to $66 \%$ during full closure from March to April 1996. The real GNP fell by 10-15\% in the West Bank and Gaza Strip from 1993 to 1997. (Yi, 1999, p.324) At that time the Palestinian Minister of Trade said: "it was a dangerous and negative impact on the economy that followed all the economic agreements of Paris Economic Memorandum.”(Joseph Ginat, 2001, p.10)

"The Wye agreement" called for Palestine to meet the trend of globalization in 1998, and implemented a freer and open economic policy, but how much did the Palestinian people really gain from this policy?

\section{The impact of globalization on the Palestinian economy}

Different from other developing countries, the Palestinian economy was control by international financial organizations from the beginning. The World Bank drafted "Emergency Assistance Program" for the Palestinian after "Oslo Agreement", which provided long-term loans through multiple channels to encourage the Palestinian to develop its private sector. The World Bank had also created the Palestinian Economic Council for Development and Reconstruction. In essence, the World Bank and International Monetary Fund played the role of the savior in aiding, organizing and designing the economic program during the Palestinian fighting for self-government and nation-building process. But the "Emergency Aid Program" or the Palestinian Development and Reconstruction Council was requested to configure assistance fund by the World Bank, International Monetary Fund and the U.S. They controlled the Palestinian economy in accordance with their wishes. This was also bound to make the Palestinian economic policy-making meet the tide of globalization, rather than on their actual needs to some extent. In this sense, many of the programs of international financial organizations might be justified and was right from the perspective of economic experts and was in line with market competition, but the Palestinians had to accept them, so their assistance plans and reform programs was a bitter pill to swallow for the Palestinians.

Firstly, fund regorged seriously. Global positioning of the Palestinian Authority encouraged domestic and foreign banks freedom of movement, and the Palestinians were free to transfer their savings abroad. According to statistics, $90 \%$ of the Palestinian had savings in Jordan banks. So these deposits were invested in accordance with the need of Jordan, not used to develop the Palestinian economy. Loan size and number of Palestinians was declining, and the harsh conditions were attached to loans. Statistics showed that the ratio of loans and deposits was $80 \%$ in Jordan, $90 \%$ in Israel, only $21.6 \%$ in the West Bank, $18.6 \%$ in Gaza in 1996 . There had a slight increase in 1997, up $28 \%$ in Gaza. But about $70 \%$ of the loans were short-term, and only $6 \%$ loans were spent on infrastructure construction, promoting economic development in deed.(Sami Al-Khazendar, 2000, p.30) Moreover, it clearly limited the maximum amount of loan in the West Bank and Gaza, and most deposits were transferred to foreign countries to obtain high interest. E.g. the deposits of individuals and private sector amounted to 938 thousand U.S. dollars in foreign banks to April 1996.Foreign deposits was as high as 10.8 billion U.S. dollars to April 1997. (Ziad Abu-Amr, 1998, p.238) From the above analysis we could seen that Palestinian funds more and more ignored the Palestinian national interests and national responsibility, and more and more national capital integrated into the international financial funds, thus national economy was increasingly fragile in the wave of globalization.

Secondly, the inflowing funds were used improperly and national funds in inferiority. Palestinian economy adopted economic policy of globalization - that was neo-liberalism which relaxed capital controls and provided various favorable conditions in order to attract foreign investment. Therefore, Palestine used a lot of investment for "special" infrastructure such as luxury supermarkets, hotels, restaurants, office buildings and so forth, to meet the needs of investors while little investment in productive industries. Such investments had reached one million U.S. dollars in the autonomous region from the Madrid peace process trigging. How much income did the people receive from these investments? To which extent were land and funds in the West Bank and Gaza directly used for the production of goods to meet the needs of the people? The following figures were imaginable. In 
1993-1998, the total amount of international aid reached 355 million U.S. dollars. It was used 2.45 billion U.S. dollars actually, but very little funds used for the production and infrastructure. GNP decreased by $3.4 \%, 10.1 \%$, $2.9 \%$ respectively in $1993,1995,1996$. The unemployment rate was as high as $30 \%$ compared with $5 \%$ before the "Oslo Agreement" in the same period. (Joseph Ginat, 2001, p.12) International financial organizations emphasized that it was key to solve the employment and maintain social stability by rapid growth in investment and capital injection so the Palestinian Authority implemented an open policy and gave privilege foreign companies. Palestine promulgated law of investment in 1996 in support of the development of foreign capital in the region. Strong foreign capital forced the domestic founds into the subcontracting works or out of business. Law of investment leaned to foreign investment so that weakened domestic items that they had small-scale and market potential thought its products met the needs of the people. The foreign capital only for profiteering had dominated in Palestine. The Palestinian people were stagnant in living standards. There had poverty rate of $43.5 \%$ in West Bank, two-thirds of Gaza's households living in extreme poverty.

Thirdly, the industrial structure had developed abnormally. As the developed countries lied in a dominant position in the globalization process, the Palestinians had to accept unequal and unjust treaties involving in the process of globalization. Western developed countries curbed the Palestinian economy by the assistance and investment from the World Bank, IMF and other international organizations. The latter could only accept the scattered low-level industry of developed countries (it was Israel in support of U.S. in the Middle East) in the international division system, leading to the uniqueness and dependence of its industry structure. Palestine based on the labor-intensive, export-oriented and low-tech type industry whose market had been occupied by Israel and Western developed countries because of its low efficiency. Industrial output accounted for less than $12 \%$ in the Palestinian GDP since 1991. The proportion of agricultural output in GDP was less than $27.1 \%$ from 1992 to 1996, resulting in products heavily dependent on imports. The trade deficit was expanding. E.g. the deficit amounted to 1.59 billion U.S. dollars in 1994.It was as high as 2.08 billion U.S. dollars in 1997. (Michael C. Hudso, 1990, p.122) The World Bank established nine industrial zone along the Green Line borders between Palestine and Israel by the investment of 500 million U.S. dollars to allow international companies and Israeli companies to produce and operate by the employment of Palestinian labor force, which led to the globalization of the Palestinian economy and labor and hindered the development of industrial sector in the West Bank and Gaza. With the full opening of these industrial zones, export-oriented agriculture would dominate and the tourism center in Jordan might also be internationalized, and many Palestinians would sell Israeli products in the Arab world. Thus would accelerate the market penetration of Israel against the Palestinians. We had to admit that the special relationship between the United States and Israel made Palestinian economy more dependent on Israel which was an indisputable fact in the United States-led peace process in the current global situation: the unemployed and the surplus labor from refugee camps and countries in rural areas eagerly hoped the Government of Israel provide them with employment opportunities; business class as a commercial agent selling Israeli goods, with the Israeli capitalist manipulated the Palestinian economy; for farmers at the lowest level of society, they were forced to produce goods that met the needs of the Israeli market, so the agricultural economy had to be subject to Israel. Not difficult to see globalization changed "Israel from the Arab world outside into the center of the Arab world, but the Palestinian economy was facing the danger of being marginalized." (Sami Al-Khazendar, 2000, p.31)

Finally, the acceptance of globalization exacerbated the polarization of Palestine to some extent. Every Palestinian was subject to excluded in the period of Israel's direct rule.

In Arafat's self-government, some senior officials filled their own pocket so that they had to act according to the rules of the game of the World Bank and International Monetary Fund in order to get their financial support. These senior officials managed Monopoly Company privately using international aid and excluded the small and weak Palestinian national private businessmen and made them in dilemma so they attained monopoly windfall. Palestinian senior officials used their acquired privileges to feather their nest and embezzle public founds in receiving assistance from international financial organizations which resulted in serious corruption within the Government. The Palestinian Legislative Council said 18 except 4 ministers in the Palestinian government had different levels of economic problems in July 1997.

\section{Conclusions}

In order to maintain and consolidate its strategic interests in the Middle East and create the economic foundation for promoting Middle East peace talks, the United States pressured the Palestinians to implement neo-liberal economic policies and reduce state intervention to meet the trend of globalization. All this measures were more dangerous for the Palestinian economy by Israeli economic control. Palestinian blindly followed free-market economic policies resulting in many problems, such as the serious reflux of the Palestinian social funds, the 
improper investment direction, abnormal structure, subject to the Israeli economy and increasingly sharp polarization and corruption. Globalization had exacerbated the Palestinian dependence, poverty and social tensions. In the globalization process, the Palestinians should seize the opportunity, adopt trade protectionism, cooperate with the Arab market and the Arab economy, punish severely corruption and strengthen government transparency and other measures so as to effectively enable the Palestinian economy through the four stages of development to implement ultimate economy independence. The four stages were: to gradually get rid of the Israeli economy ---- with the unequal cooperation of the Israeli economy ---- with the equal cooperation of the Israeli economy ---- with the Arab economic integration. No government could say "no" in the process of globalization. "Bravely meet the challenge only facing reality."(Sami Al-Khazendar, 2000, p.31) The appeal of Algerian President Abdelaziz Bouteflika had become the small and weak nations' common aspiration in the globalization because they all sought survival and development. After the signing of "Oslo agreement", the late President Arafat made a speech to appeal that the Palestinian people should seize the opportunities, avoid disadvantages, improve the development, reverse the comparative disadvantages of the status in peace talks and found a solid economic base, which should be Palestinian priority.

\section{References}

Joseph Ginat. (2001). the Jordanian-Palestinian-Israeli Triangle: Smoothing the Path to Peace. Journal of Palestine Studies. Vol.xxx, No.4.

Liu Li \& Zhang Chang. (1997). Economic Globalization: Luck or Disaster. Beijing: China Social Press.

Michael C. Hudso. (1990). The Palestinians: New Directions, Center for Contemporary Arab Studies. Washington: Georgetown University.

Sami Al-Khazendar. (2000). Isreal and the Palestine Question: Left Forces in Foreign Policy-Making. Journal of palestine studies, Vol.xxix, No.2.

Yi Chongjing. (1999). One Hundred Years of the Middle East. Beijing: Xin Hua Press.

Ziad Abu-Amr. (1998). The Palestine Uprising in The West Bank and Gaza Strip. Arab Studies Quarterly, Vol.10, No.4. 